\title{
Afterword: Outlines of a New Roadmap
}

\author{
Egil Asprem and Julian Strube
}

We opened this volume by observing that esotericism scholars' scope is undergoing a phase of geographical, cultural, and demographic expansion. With these developments comes the need for theoretical and methodological reflection. As scholars are now once again inquiring about esotericism in a global context - not as part of a phenomenological comparative program, but as a critical historical undertaking - it has become clear that some of the field's core assumptions and key terminology must be rethought. The chapters of this book have demonstrated this need in a number of different ways, and put theoretical tools and existing scholarly literatures on the table that would help the field succeed at the task.

If there is one central assumption that rises above all others, due to its centrality to the field and the way its consequences make themselves felt on a number of different issues, it is the Eurocentrism embedded in the notion that esotericism is specifically "Western." Chapters in this book have drawn on a number of scholarly literatures that critique this issue in different but compatible ways, notably postcolonial studies and global history (Strube, 2021), decolonial approaches (Villalba, 2021, Page and Finley, 2021), and critical race and whiteness studies (Bakker, 2021). The chapters demonstrate that, contrary to some polemical framing that has now become fashionable even in the field of esotericism, these approaches are not out on an iconoclastic mission to demolish Western civilization and denigrate its values: they are about doing historical and social-scientific work in a theoretically and methodologically more substantiated way. This means taking into account the complexities and contingencies, the ambiguities and contradictions, and the ruptures and continuities of the historical developments that have shaped not only understandings of "Western civilization," but of "esotericism" as well. Decades of scholarship have demonstrated how diffusionist assumptions about the unilateral spread of Western knowledge have obstructed our understanding of such complexities and still play a crucial part in present-day scholarly and political polemics.

What we have called the "diffusionist reaction" to global approaches in the study of esotericism is exemplary not only of the neglect but also of the outright misrepresentation of such insights, and also illustrate a lack of (self-)reflection on the positionality of those who, today, carry out historical or socialscientific research on esotericism. In this sense, we hold that the structural analysis of biases and power inequalities that is of major concern for post- 
colonial, (global) historical, or critical-theoretical approaches are tools that will ultimately equip us to uncover sources, voices, historical relationships, and entanglements that we had ignored — not because they weren't there, but because we were systematically looking the other way. The consequences of engaging these frameworks seriously and thereby challenging the field's Eurocentrism when we start studying esotericism around the world are that the "Western" moniker should be dropped, along with the diffusionist representations that come with it and that have so far dominated attempts to study esotericism outside its imagined occidental homeland.

Why is this important? The key reason, discussed in several chapters of this book, has to do with a basic concept of historical analysis and interpretation: agency. This notion signifies the capabilities of historical actors to shape history, which is conditioned and structured by their individual embedment in complex historical contexts. The diffusionist frameworks have, as we think is now well demonstrated, led to a selective and distortive attribution of agency to historical actors. It has essentially meant following the activities of the Western, often European, usually white and mostly male actors already well-known to esotericism scholars, and prioritizing their creative activities and contributions even when these contributions are clearly negotiated in non-European contexts - to the occlusion of non-white, non-Western actors. The effect is a self-sustaining and circular line of scholarship, which cannot fail to reproduce its own assumptions because it only selects sources capable of confirming them. Put differently, the critical approaches introduced in this book are a remedy against the field's persistent confirmation or "myside" bias.

The paradigmatic example, as discussed by Strube (2021) and Cantú (2021), is the activities of occultists in India, such as the Theosophical Society and various occultist engagements with yoga, but we have seen the same logic applied to South America, the entire Islamic world, and the descendants of the Atlantic slave triangle's displaced bodies. Reclaiming and making space for subaltern voices, then, must be a major project for a global study of esotericism. While most chapters have focused on the theoretical prerequisites for this project, it bears emphasizing that the realization of the project must above all be a revision in methodology: giving space for subaltern voices requires selecting different sorts of material, reading different languages, and perhaps even embracing alternative modes of scholarly representation, as was argued and effectively illustrated by Finley and Page's flash non-fiction exercise as part of their recovery of Africana esoteric discourse through the lyrics and material culture of soul and blues music.

The issues of agency, subaltern voices, selection of sources, and scholarly representations of the same are not only relevant for the discussion of eso- 
tericism globally; they also bear on the question of an historical expansion of the field, and its relationship with other fields and disciplines. The study of esotericism holds enormous potential for entering dialogue with, significantly enrich, and even transform the perspectives of other fields of study. It is able to demonstrate the outstanding but notoriously neglected importance of currents such as Theosophy or occultism, not only in terms of historical relevance but also in light of theoretical and methodological approaches and concepts. Esoteric contexts often function like a burning glass for controversially debated issues such as agency, colonialism, racism, gender, or "appropriation" and "authenticity." This is not least because of esotericism's constant tendency to defy modern categorizations (e.g. the religion-science-magic triad; high and low culture; the political right-left spectrum), a fact which indeed has been a major contribution of the field as a whole. The concentrated study of how esotericism is entangled with debates of colonialism, gender, racism, etc. offers instructive insights into the often ambivalent negotiations and performances of identities, not only in light of broader political or cultural trends, but also, as Hedenborg White has demonstrated in her chapter (2021), of gender, sex, and sexuality.

The scholarship that formed the basis of the various chapters of this volume is concerned with unraveling such intricacies. That does not mean "eagerly deconstructing Western culture," but explaining how "it" was subject to constant renegotiations and transformations, in which esotericism played a crucial and still under-studied part. In this sense, the study of esotericism should also complicate both the ideas of a unilateral spread of some knowledge from the West to the East and the unilateral "appropriation" of other knowledge from the East by the West. These ideas do not only mark predominant approaches within the study of esotericism, but also more extreme postcolonial views on the colonial context as exclusively determined by oppression, exploitation, and cultural incommensurability. From both angles, the agency of "non-hegemonic" actors is historiographically obscured. At a time when such issues are the subject of prominent academic and socio-political debates, the study of esotericism could make a significant and valuable contribution on the basis of a revised and substantiated toolkit that would break the self-referential circle, complicate ongoing polemics, and attract the attention of other scholars and institutions.

To this end, it is imperative to rethink the categories at work within the study of esotericism, including its conceptualization as a dustbin of rejected knowledge. As Burns (2021) has demonstrated, esotericism scholars often operate with categories that are ahistorically projected on earlier source material, without sufficiently engaging with the expertise of the fields of study ded- 
icated to them. Not only does this contribute to the self-isolation and selfmarginalization of the field because of a lack of interdisciplinary dialogue and scholarly rigor; it also perpetuates the historiographical marginalization of its subjects, which, as Asprem (2021) points out, often enough were anything but marginal or rejected. One crucial step to counter these perceptions is a methodological focus on the reception history of historical subjects, the fruitfulness of which becomes evident in Burns' treatment of "gnosis." Such an approach harmonizes well with the genealogy proposed by Strube, in demonstrating how historical narratives and polemics have shaped and often distorted the perception of historical sources and their contexts up to the present day. While a call for "strictly historical" approaches and an awareness of the polemical and/or retrospective construction of esotericism as rejected knowledge are by no means absent from earlier scholarship, Burns' chapter further underlines that such calls have not always been consistently and thoroughly carried out. These shortcomings also reveal themselves in the neglect of Islamicate contexts examined by Saif, which ironically shaped much of the historical material-such as Hermetism - that is often considered an integral part of "Western" esotericism. When we further consider that there are more texts dedicated to Hermes in Arabic than in any other language (van Bladel, 2009), it becomes all the more reasonable to decenter the particularly European and Christian reception that has been given pride of place so far, and present it instead as just one among many receptions of Hermetic writings.

The study of esotericism as rejected knowledge also carries great potential for contributing to broader discussions in the humanities if it is done right. As Asprem argued in his chapter, doing it right would mean scrapping the inflated version of the thesis, which risks amounting to hyperbolic statements about the field as the ultimate victim of hegemonic knowledge systems, while at the same time contradicting the likely results of in-depth analyses of rejection processes, marginalization, and distributions of power-or worse, making such analyses impossible. By contrast, the strict version of the rejected knowledge model has a lot to offer to broader understandings of modernity, and especially the impact of the Reformation and the Enlightenment on the formation of a modern "historical a priori" or tacit knowledge of what counts as acceptable claims. In particular, this aspect of esotericism has much to gain from integrating with a broader sociology of knowledge and related perspectives, whether in the history of religion, science, or medicine. To begin with, this is, as Asprem noted, because the stigmatization of knowledge systems or particular knowledge claims can happen in many different ways and for different reasons-from explicit rejection by specific authorities, to shifts in orientation by knowledge users and producers resulting in forgetfulness and 
replacement, to the ignoring of low-prestige knowledge not considered worthy of attention in the first place.

Moreover, the study of modern and contemporary esotericism offers excellent opportunities to study the complex effects and diverging motivations behind the production of esoteric ideas and practices as being somehow marginal or even subversive. As Asprem also highlighted, such status seems in fact to be an integral component of what makes esotericism attractive as an "alternative" to "official" positions, whether in the domains of religion, arts, politics, medicine, worldviews, or "lifestyles." Crockford's chapter (2021) further illustrated how this aspect troubles the view of esoteric rejected knowledge as the essential "underdog," divested of "Establishment" power, by showing how the rhetoric of being rejected, marginal, oppositional and, moreover, secret, is used successfully in marketing purposes by the wellness industry. The thrust of Asprem's and Crockford's arguments is that a critical reappraisal of how rejected knowledge narratives are constructed leads us to consider the agency of those who are either "rejected" by others, claim such status for themselves, or gravitate towards that which has already been construed as marginal. Further studies along these lines can contribute a lot to our understanding of more general processes of exclusion and opposition, which seems crucial at a time when anti-Establishment rhetoric is a potent political force in the world.

\section{Conceptualizing “Esotericism” for a New Generation}

The focus of this book has been on how we can responsibly and fruitfully expand the perimeters of the study of esotericism. The responses to this question - and the particular recommendations to drop the Western demarcation, avoid diffusionist models, readjust our foci on (historical) actors, and rethink the rejected knowledge thesis-inevitably brings us back to the question of how esotericism ought to be defined. We can hear the worries of some readers that there will be nothing left of the field once the reflection is done, or that a global approach on non-diffusionist terms leaves us with a concept so diluted that it signifies anything and nothing, anywhere and nowhere. Let us in conclusion address this worry by showing that, to the contrary, we have a lot left to work with, and clear directions for a plurality of different research projects where esotericism can be operationalized on lucid and sound foundations.

As Okropiridze (2021) argued in his philosophy-inflected contribution on the definitional progression in the field, there is currently an unresolved tension between definitions that claim to be grounded in the way things are 
(what he calls the onto-epistemological directionality) and approaches that hold esotericism to be a human (scholarly or otherwise) projection onto reality (historical, social, psychological or otherwise; what he calls the epistemoontological directionality). In the first camp he singles out Faivre's definition as the gold standard, while elements of it are also found in Hanegraaff's empiricist project of letting sources speak for themselves and in Asprem's cognitivist project of studying the mental and evolutionary building blocks of practices deemed esoteric. In the second camp he singles out Bergunder's approach to esotericism as an "empty signifier" that temporarily fixes contentious power discourses in concrete historical contexts as the clearest example, while again also finding elements of it in Hanegraaff's insistence that esotericism emerged as a narrative construct shaped in polemical discourses, and Asprem's insistence that the cognitive building blocks are not building blocks of esotericism (constituting and defining it), but rather of individual practices that are labelled such in various discursive formations (and yet differently in other formations).

Okropiridze's conclusion is worth noting, for it offers consolation to those who worry that scholars will have nothing left to work with following theoretical interventions of the type offered in this book, or that the field will be dominated by "deconstructions." To the contrary, Okropiridze argues that neither the "deconstructionist" nor the "inductivist-realist" side of the spectrum can succeed on their own, because the nature of interpretation requires both that there is something revealing itself to be interpreted (the onto-epistemic, or realist presupposition) and that something is singled out for interpretation by the scholar (the epistemo-ontological, or "deconstructionist" presupposition). Since Okropiridze thinks this conundrum cannot be solved, his prescription is that we must allow for differing approaches and, indeed, definitions, to work side by side in the field - on the condition that each research program selfreflectively acknowledges their limitation, restrains any ambition for dominance, and listens attentively to what other projects built on different assumptions are achieving.

In that spirit, let us now return to the definition question as it looks in light of the chapters of this book. While the definition debate has not been at the forefront, we have seen several strategies deployed throughout the book, notably a consistent genealogical approach based on Bergunder (Strube), and stipulative, heuristic definitions singling out specific understudied subfields, such as "ancient (Mediterranean) esoteric traditions" (Burns) and "Africana esoteric studies" (Page and Finley). These approaches work in opposing directionalities, to use Okropiridze's terminology, but can, as we will show, still fruitfully speak to one another. 
The first thing to make clear is what is and is not entailed by the genealogical approach that Strube suggests as the basis for a global history of esotericism. First of all, while it is true that it dismisses the possibility of simply uncovering a set of sources out there that can be made to speak for "esotericism," it does not follow that we thereby lose access to our sources, that esotericism doesn't "really exist," or that anything could be made into esotericism on the scholar's whim. What the approach leaves us with in terms of defining a field of study is in fact very precise and empirically accessible: starting with the existence of the term itself, it points us to the discourses in which it is articulated, by real flesh-and-blood people, along with the contexts in which they live and act, and asks us to pay attention to the meaning-making processes and negotiations over the term's significance in those contexts and to those people. Working our way backwards, we land in the nineteenth century as the crucial period in which meanings of esotericism are enunciated, connected with ancient wisdom traditions, initiations, secrecy, magical power, tantra, mesmeric trance and somnambulism, hidden Tibetan masters, yoga, gnosis, perennial truth, astral travel, and all the rest. As Strube demonstrates, this genealogical foundation then requires us to decenter the particular voices we have been used to prioritize and analyse the entire discourse on the esoteric/esotericism where, e.g., South Asian individuals and organizations, as well as rank-and-file Indian members of the Theosophical Society are given equal attention, and their own local motivations, background knowledge, and pre-Theosophical horizon of meaning are explored for how they actively shaped the negotiations that ensued. A crucial insight resulting from this perspective is that the meanings of notions such as esotericism, occultism, or Theosophy were anything but fixed and subject to constant controversial negotiations - they were not ready-made "Western concepts" that could be exported into the rest of the world. Quite the contrary, they were shaped within global exchanges. As Cantú demonstrated with regards to the study of yoga, this tracking of existing local traditions, practices, and meanings has already turned up lots of empirical evidence that causes significant problems for the narrative of Western occultists simply "appropriating" an authentic yoga and adapting it to comply with "essentially Western" ideas. Instead we see genuine entanglements of pre-existing Indian and European traditions that mutually influence each other.

Some might object that a genealogical approach will run into problems if it wants to push further back in history to times before there was a discourse on "esotericism" (because the term was not yet coined). For such an expansion to succeed, it will usually be necessary to invent analytic concepts for heuristic purposes, or to follow other "empty signifiers" (such as "gnosis," "kabbalah," or "magic") that made it into the temporary fixing of "esotericism." In fact, the ge- 
nealogical approach does already provide us with crucial insights that must be taken into account if we are to stipulate definitions to be deployed backwards in history. It is also well equipped to conceptualize responsible comparative projects, as it consistently works through the contextualization of historical sources (Bergunder, 2016). For example, it is already clear that, while "esotericism" as such is empty, the connections that the term fixed in nineteenthcentury discourses tended to draw on a number of rather specific ideas, particularly when narratives of tradition were invented. As is well known, Jacques Matter was first to define the term in French as denoting the elitist secrecy that he associated with Gnosis and ancient Gnosticism-significantly influenced when doing so by existing Illuminist currents in France that combined initiatory societies with magical and theurgic practice, divination, and oracles. In the German context, the noun Esoterismus was first used in discussions about Pythagoreanism and their apparent secret societies, while it soon also came to be used in the context of Freemasonry, across the continent as well as in English (Neugebauer-Wölk, 2010). It bears emphasizing that the earliest authors who used such vocabulary did so in the context of orientalist studies and, like Matter, linked Gnostic doctrines to common civilizational roots in "India" and "the East" from the very beginning (Strube, forthcoming; cf. 2016b, pp. 115-121 and passim). Among the occultists, invocations of esotericism or "esoteric tradition" would seldom fail to reference the Gnostics, kabbalists, mystery cults, Hermes Trismegistus, Pythagoras, Plato, the Neoplatonists, the Knights Templars, the Cathars, the Rosicrucians, the alchemists, and so forth. It did not take occultists long, then, to embark on journeys to "the East" on their quests for the origins of the ancient wisdom supposedly handed down by these traditions. A genealogical perspective offers explanations of this circumstance on the basis of historical source material and investigates how and why historical actors identified and compared "esoteric traditions" across the globe.

Such a perspective also helps to understand the emergence of such (invented) traditions. Esoteric narratives and ideas emerged and were shaped in all sorts of different contexts and for different reasons: as Strube has shown elsewhere (2016a), the first occultists did it in the very specific contexts of French pre-Marxist "utopian socialism" and neo-Catholicism-and emphatically not in the context of an actually existing tradition where these systems were passed down in an unbroken chain that can simply be studied historically. Yet, the meanings and connections that such enunciations assembled provide us with a framework for further, necessarily more fragmented, historical studies along the lines of reception history. It is precisely through such a lens that the study of esotericism could demonstrate the relevance of its subjects, and thus its own relevance: orientalist studies, historical-critical Bible 
studies, socialism, and the most influential Catholic movements at a given time were anything but rejected or marginal. A consistent pursuit of such a research program could thus not only yield crucial insights into historical and social-scientific material; it also could help other scholars understand the history of their subjects, for instance by demonstrating the relevance of esotericism within the history of socialism. It could also help them understand the history of their disciplines: even a cursory look at Indological scholarship or studies focusing on late antiquity, for instance, will reveal an abundance of "esoteric" vocabulary.

This is also where we can see how Burns' suggestions complement the genealogical approach, which starts by stipulating "ancient (Mediterranean) esoteric traditions," which is to cover religious and philosophical traditions in the ancient world centrally concerned with an "esoteric" dynamic of hiding and revealing higher truths usually held to be ineffable, whether we find these in Neoplatonic theurgic traditions, Gnostic apocalyptic texts, or the Enochic literature of Jewish apocalypses. Having defined this area of interest, Burns suggests we can fruitfully build our way through history, not by tracing "surviving traditions" from antiquity, but through a reception-historical approach in which the memory of and references to such texts, whether in existing manuscripts or fragmentary reconstructions, have constantly been reinterpreted and reimagined over the first millennium, into the European Renaissance and down to our own days. Eventually, then, these two approaches meet in the fixing of discourses on "esotericism" - the crucial point is that while these discourses retroactively point out the direction for us of what's relevant to study, the critical reflection on how those connections were fixed should enable us to resist simply reproducing, for instance, nineteenth century historical narratives. Any ancient sources we end up studying, then, are not sources "of" esotericism (strictly speaking invented in the eighteenth and nineteenth centuries), even though their reception history and their later entanglements eventually contributed to the formation of "esotericism" as an empirically available historical subject matter in the modern colonial period.

Along the way, scholars get plenty of opportunities to study the social roles of secrecy and initiation, the construction of tradition, the production and contestation of knowledge, and rejection and exclusion practices-as well as the shifting ways in which this material is connected with political, economic, and religious power. Not least due to the oppositional and non-hegemonic status that is often ascribed to esotericism by practitioners, their critics and opponents, or scholars studying them, this material holds huge potential for analyses of social practices and socio-political issues. Several chapters in this volume have highlighted this potential with regard to sexuality, gender, and 
race. It is in light of such examples that the study of esotericism can make significant contributions, not only to research on historical subjects but also on how they inform and shape present-day developments.

All of this should suffice to illustrate that there is a vast continent of material left to study with such conceptualizations of "esotericism." While it does not lead to an "anything goes" attitude, it does open up the field in very significant ways. For example, Burns' reception-historical approach could equally validly be applied in the South Indian context, as indeed Cantú does in his chapter, or in the context of South and Latin America, as indicated by Villalba, and obviously too in the Islamic world, as Saif argues. Rather than escalating into a diffuse or even neo-perennialist historiography, or attempting to write a "universal" or "planetary" history of esotericism, the decentered and global approaches suggested in this volume form solid foundations for strictly historical, consistent, and theoretically substantiated research. Equipped with such a roadmap, we invite scholars of esotericism as well as outside observers to explore the expanding horizon of our field and secure not only its internal solidification, but also its establishment within academia at large.

\section{Bibliography}

Asprem, E. (2021) "Rejected Knowledge Reconsidered: Some Methodological Notes on Esotericism and Marginality," in Asprem, E. and Strube, J. (eds.) New Approaches to the Study of Esotericism. Leiden and Boston: Brill, pp. 127-146.

Bakker, J.M. (2021) "Race and (the Study of) Esotericism," in Asprem, E. and Strube, J. (eds.) New Approaches to the Study of Esotericism. Leiden and Boston: Brill, pp. $147-167$.

Bergunder, M. (2016) "Comparison in the Maelstrom of Historicity: A Postcolonial Perspective on Comparative Religion,” in Schmidt-Leukel, P. and Nehring, A. (eds.) Interreligious Comparisons in Religious Studies and Theology. London/New York: Bloomsbury Academic, pp. 34-52.

Bladel, K.v. (2009) The Arabic Hermes: From Pagan Sage to Prophet of Science. Oxford: Oxford University Press.

Burns, D. (2021) "Receptions of Revelations: A Future for the Study of Esotericism and Antiquity," in Asprem, E. and Strube, J. (eds.) New Approaches to the Study of Esotericism. Leiden and Boston: Brill, pp. 20-44.

Cantú, K. (2021) “'Don't Take Any Wooden Nickles': Western Esotericism, Yoga, and the Discourse of Authenticity," in Asprem, E. and Strube, J. (eds.) New Approaches to the Study of Esotericism. Leiden and Boston: Brill, pp. 109-126. 
Crockford, S. (2021) “What Do Jade Eggs Tell Us about 'Esotericism”? Spirituality, Neoliberalism, Secrecy, and Commodities," in Asprem, E. and Strube, J. (eds.) New Approaches to the Study of Esotericism. Leiden and Boston: Brill, pp. 201-216.

Hedenborg White, M. (2021) "Double Toil and Gender Trouble? Performativity and Femininity in the Cauldron of Esotericism Research," in Asprem, E. and Strube, J. (eds.) New Approaches to the Study of Esotericism. Leiden and Boston: Brill, pp. 182-200.

Neugebauer-Wölk, M. (2010) "Der Esoteriker und die Esoterik: Wie das Esoterische im 18. Jahrhundert zum Begriff wird und seinen Weg in die Moderne findet," Aries, 1O(2), pp. 217-231.

Okropiridze, D. (2021) "Interpretation Reconsidered: The Definitional Progression in the Study of Esotericism as a Case in Point for the Varifocal Theory of Interpretation," in Asprem, E. and Strube, J. (eds.) New Approaches to the Study of Esotericism. Leiden and Boston: Brill, pp. 217-240.

Page, H.R. Jr. and Finley, S.C. (2021) “'What Can the Whole World Be Hiding?' Exploring Africana Esotericisms in the American Soul-Blues Continuum," in Asprem, E. and Strube, J. (eds.) New Approaches to the Study of Esotericism. Leiden and Boston: Brill, pp. 168-181.

Saif, L. (2021) “That I Did Love the Moore to Live with Him': Islam in/and the Study of "Western Esotericism,"' in Asprem, E. and Strube, J. (eds.) New Approaches to the Study of Esotericism. Leiden and Boston: Brill, pp. 67-87.

Strube, J. (2016a) "Socialist Religion and the Emergence of Occultism: A Genealogical Approach to Socialism and Secularization in 19th-Century France," Religion, 46(3), pp. $359-388$.

Strube, J. (2016b) Sozialismus, Katholizismus und Okkultismus im Frankreich des 19. Jahrhunderts: Die Genealogie der Schriften von Eliphas Lévi. Berlin/Boston: De Gruyter.

Strube, J. (2021) "Towards the Study of Esotericism without the 'Western": Esotericism from the Perspective of a Global Religious History," in Asprem, E. and Strube, J. (eds.) New Approaches to the Study of Esotericism. Leiden and Boston: Brill, pp. $45^{-66 .}$

Strube, J. (forthcoming) Tantra in the Context of a Global Religious History (working title).

Villalba, M. (2021) "The Occult Among the Aborigines of South America? Some Remarks on Race, Coloniality, and the West in the Study of Esotericism," in Asprem, E. and Strube, J. (eds.) New Approaches to the Study of Esotericism. Leiden and Boston: Brill, pp. 88-108. 